\title{
Oxidative Stress for Smoking Persons in Suburbs Mosul City*
}

\author{
Tareq Y. Ahmad \\ Department of Chemistry \\ College of Science \\ Mosul University
}

(Received 13/7/2008; Accepted 27/10/2008)

\begin{abstract}
The study was conducted in Mosul-suburb to show the effects of smoking on antioxidants and some biochemical parameters which include: Vitamin E, Vitamin A, $\beta$ carotene, Vitamin C, Folic acid, Ceruloplasmin (Cp), Total protein, Albumin, Calcium, Total bilirubin, Direct bilirubin, Uric acid, Creatinine, Total iron binding capacity (TIBC), Iron, Sulfate, Glutathione(GSH), Malondialdehyde (MDA), Cholesterol, Glucose, Selenium and Transferrin saturation(\%). The study included (102) persons living outside city center represented into two minor groups, smokers and non smokers.

The results showed that the level decreased significantly in rural smokers when compared with rural non smokers in: vitamin $\mathrm{C}$, total bilirubin, direct bilirubin and MDA, and there was a significant increase in: vitamin A and Cp., but there wasn't any significant changes in: total protein, albumin, uric acid, creatinine, TIBC, iron, sulfate, cholesterol, selenium, calcium, vitamin E, $\beta$-carotene, folic acid, GSH, glucose and transferrin saturation(\%). Depending on the period of smoking, the results predicted that antioxidants and some other parameters (vitamin $\mathrm{E}$, vitamin $\mathrm{A}, \beta$-carotene, vitamin $\mathrm{C}$, folic acid, total protein, albumin, calcium, total bilrubin, direct bilirubin and GSH) were decreased, while: Cp., uric acid, creatinine, TIBC, Iron, sulfate, MDA, cholesterol, glucose and selenium were increased with increased the period of smoking.

\section{الكرب التأكسي المنخنين في ضولي مدينة الموطل}

\section{الملغص}

شملت الدرلسة تأثير التخن على مضادات الأكسة وبعض المتغيرات الكيموحيوية في ض -ولجي

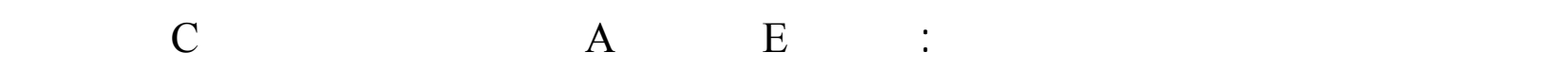

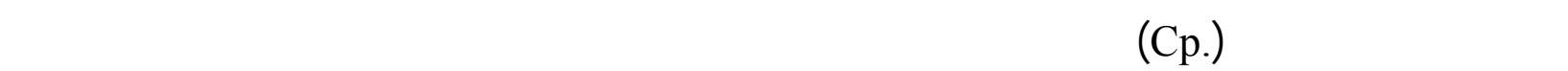

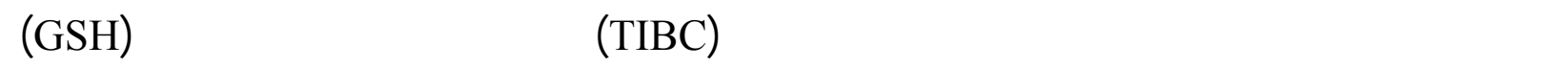

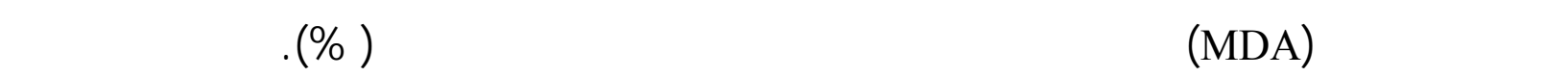

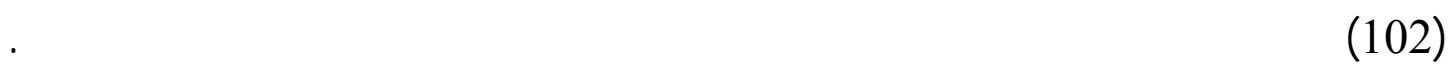

*م إقاه بالمؤتمر العله الأول للكيمياء المنقدد بتاريخ 22-23 نيسان 2008 فى قسم الكيمياء /كلية العلوم/جلمعة الموصل 


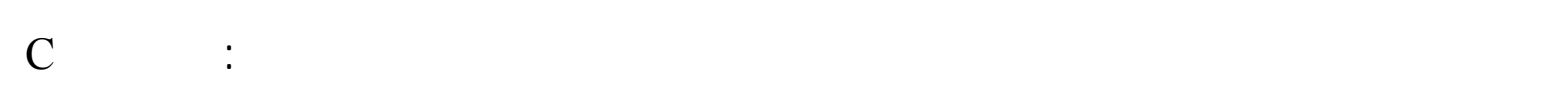

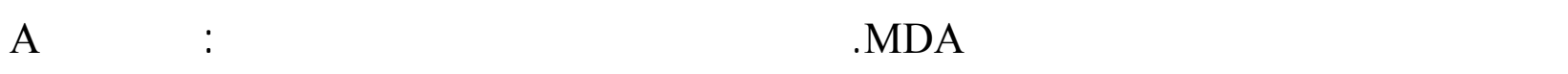

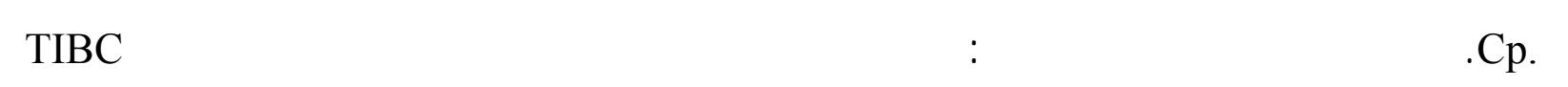

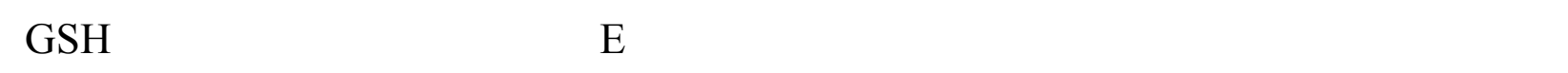

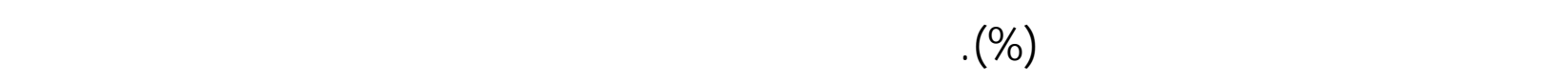

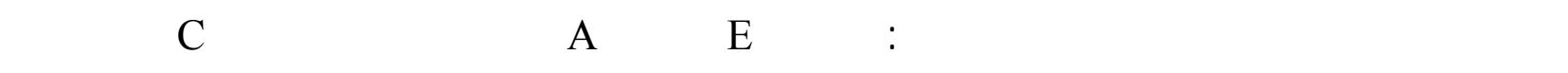

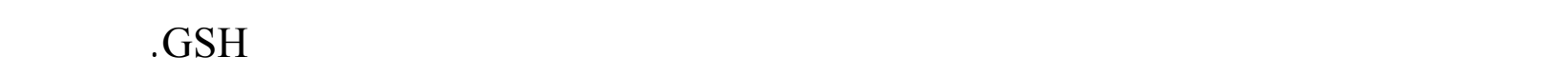

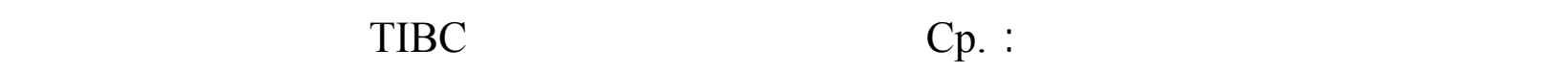

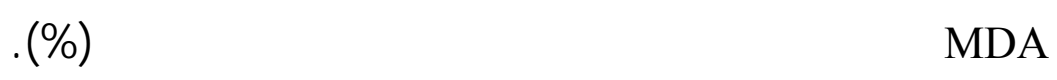

\section{INTRODUCTION}

Smoking and related diseases account for approximately 440,000 American deaths every year. This number includes both the direct effects of smoking on the smoker, but also indirect effects of smoking, such as premature births and the effects of second hand smoke .The costs are enormous. Estimates of costs of smoking, both in terms of health care costs and related to lost productivity, are between 100-150 billion dollars each year (Zheng, 2003).

Cigarettes smoke contains carbon monoxide and free radicals which are generated because of high temperatures (up to $900{ }^{\circ} \mathrm{C}$ ) at the burning tip (Gillham et al.,2000).

The free radicals found in the tar phase are different to those in the gas phase with respect to stability and half-life. The tar phase contains long-lived and fairly stable radicals. It also contains transition metal ions, which can drive the formation of the reactive hydroxyl radical. The gas phase contains short-lived reactive radicals such as nitric oxide ( $\mathrm{NO}$ ). In the presence of oxygen, this is oxidized to nitrogen dioxide radicals, which can damage lung tissue (Gillham et al., 2000):

$$
\mathrm{NO}+1 / 2 \mathrm{O}_{2} \longrightarrow \mathrm{NO}_{2}
$$

and contain reactive olefins and dienes.

A major exogenous source of free radicals is the cigarette smoke. The cigarette smoke is a complex mixture of approximately 5000 chemical compounds, including high concentrations of free radicals and other reactive oxygen species. These oxidants are contained in both the tar and gas phases of cigarette smoke. The gas-phase reactive oxidants are both inorganic and organic in nature, and include epoxides, peroxides, nitric oxide (NO), nitrogen dioxide, peroxynitrite (ONOO-), perinitrates, carbon monoxide, ammonia, dimethylnitrosamine, formaldehyde, hydrogen cyanide, acrolein and a myriad of other free radicals. Indeed, it has been reported that gas-phase cigarette smoke contains approximately one quadrillion radicals per puff. These represent an enormous oxidant load to body tissues (Zheng, 2003).

Damage to DNA appears to involve a complex of polyphenolic tar components with DNA, followed by production of the hydroxyl radical that nicks DNA (Zheng, 2003). 
Health disease and lung cancer comprise the vast majority of deaths caused by smoking, followed by chronic bronchitis, strokes, peripheral vascular disease and other cancers.

\section{Materials and Methods}

Kits for determination of Total Protein No.(0303), Albumin No. (0801), Calcium No.(2403), Total Bilirubin and Direct Bilirubin No.(0401),Iron No. (0502), Total Iron Binding Capacity No. (0512), Glucose No.(0903), Cholesterol No.(0603), were obtained from Syrbio kits, Syria.

But other biochemical parameter (Vitamin A, $\beta$-carotene, vitamin E, vitamin $\mathrm{C}$, Folic acid, Malondialdehyde, Glutathion, Selenium, Uric acid and Creatinine), determination used manual methods (Table 1).

Table 1:Methods used to determination of biochemical parameters.

\begin{tabular}{|c|c|c|c|}
\hline No. & Parameters measured & Method used & Source \\
\hline 1 & Vitamin A & Needld-Pearson method & Neeld and Pearson, 1963 \\
\hline 2 & $\beta$-carotene & Needld-Pearson method & Neeld and Pearson, 1963 \\
\hline 3 & Vitamin E & Emmerie-Engel reaction & Emmerie and Engel, 1938 \\
\hline 4 & Vitamin C & $\begin{array}{c}\text { 2,4-dinitrophenylhydrazine derivatization } \\
\text { method }\end{array}$ & Roe and Kuther, 1943 \\
\hline 5 & Folic acid & Microbiologyical assay & AOAC, 1950 \\
\hline 6 & Glutathion & $\begin{array}{l}\text { Modified procedure utlilizing Ellman`s } \\
\text { reagent. }\end{array}$ & Sedlak and Lindsay, 1968 \\
\hline 7 & Malondialdehyde & Thiobarbituric acid method & Lunec, 1990 \\
\hline 8 & Uric acid & Phosphotungstic acid method & Varley, 1967 \\
\hline 9 & Total bilirubin & Diazo method & Toro and Ackermann, 1975 \\
\hline 10 & Direct bilirubin & Diazo method & Toro and Ackermann, 1975 \\
\hline 11 & Total protein & Biuret methods & Kingsley, 1942 \\
\hline 12 & Albumin & $\begin{array}{l}\text { Bromocresol green mthod (dye binding } \\
\text { method) }\end{array}$ & Doumas et al., 1971 \\
\hline 13 & Ceruloplasmin & p-Phenylenediamine oxidase method & Sunderman and Nomoto, 1970 \\
\hline 14 & Glucose & Glucose oxidase method & Trinder, 1969 \\
\hline 15 & Cholesterol & Cholesterol estrase methods & Richmond, 1973 \\
\hline 16 & Creatinine & Jaffẽ method & Jaffě, 1886 \\
\hline 17 & $\begin{array}{c}\text { Total Iron Binding } \\
\text { Capacity }\end{array}$ & Ramsay method & William et al., 1977 \\
\hline 18 & Transferrin saturation & $\begin{array}{c}\text { Transferrin saturation }(\%)= \\
\text { Serum Iron /TIBC X } 100\end{array}$ & Burtis and Ashwood, 1999 \\
\hline 19 & Iron & Bathophenanthroline method & Burtis and Ashwood, 1999 \\
\hline 20 & Calcium & Methylthymol blue method & Rbertson and Marshall., 1979 \\
\hline 21 & Selenium & Selenium-orthophenylenediamine compex & Snell, 1981 \\
\hline
\end{tabular}

For determination of Body Mass Index (BMI) calculated using the formula as weight (kg)/height2(m2) (Al-Abbad and Al-Sowielem, 1998).

The study included (102) persons (59 nonsmokers, 43 smokers) healthy subjects, with comparable age, all were males with minimal or no risk of exposure to a polluted 
atmosphere. They were farmers living in Al-Khather village (30 km east of Mosul city center).

For venipuncture, $10 \mathrm{ml}$ sterile syringes equipped with $(22 \mathrm{G} \times 1.25)$ syringe needles were used and put in dry and clean plain tube. After coagulation, it was centrifuged at $4000 \mathrm{x}$ g for 15 minute. Serum was transferred into plain tube equipped with tight-fitting caps by disposable tips, then stored at $-20{ }^{\circ} \mathrm{C}$ (Liang et al., 1989).

\section{RESULTS AND DISCUSSION}

The results of smokers and non-smokers groups in suburbs group were listed in Table (2).

Table 2: The biochemical parameters of suburbs non-smokers and smokers

\begin{tabular}{|c|c|c|c|c|c|c|c|c|}
\hline \multirow{2}{*}{ Parameters } & \multicolumn{2}{|c|}{ Suburbs } & \multicolumn{2}{|c|}{$\begin{array}{r}\text { non-smokers } \\
(\mathrm{n}=59)\end{array}$} & \multicolumn{4}{|c|}{ Suburbs smokers $(n=43)$} \\
\hline & mean & SD & Min. & Max. & mean & SD & Min. & Max. \\
\hline Age(year) & 35.7 & 10.9 & 17.0 & 74.0 & $32.4^{*}$ & 8.77 & 17.0 & 65.0 \\
\hline Weight(kg) & 76.31 & 14.5 & 55.0 & 108.0 & $80.34 *$ & 14.6 & 52.0 & 118.0 \\
\hline Height(cm.) & 169.0 & 10.5 & 149.0 & 198.0 & 171.2 & 8.5 & 146.0 & 196.0 \\
\hline B.M.I(k.g./m²) & 26.71 & 2.45 & 24.77 & 27.54 & $27.41^{*}$ & 2.08 & 24.39 & 30.72 \\
\hline Vit.E(mg/dl) & 1.0 & 0.21 & 0.05 & 1.78 & 0.97 & 0.45 & 0.10 & 1.69 \\
\hline Vit.A( $\mu \mathrm{g} / \mathrm{dl})$ & 46.42 & 12.4 & 18.42 & 84.2 & $44.9 *$ & 8.1 & 15.1 & 68.5 \\
\hline$\beta$-carotene $(\mu \mathrm{g} / \mathrm{dl})$ & 80.49 & 21.5 & 69.8 & 253.2 & 65.05 & 12.2 & 59.45 & 247.2 \\
\hline Vit.C(mg/dl) & 0.85 & 0.17 & 0.04 & 1.87 & $0.61 *$ & 0.15 & 0.04 & 1.69 \\
\hline Folic $\operatorname{acid}(\mathrm{ng} / \mathrm{ml})$ & 6.85 & 1.7 & 3.03 & 12.76 & 6.68 & 1.1 & 4.84 & 10.06 \\
\hline Cp.(mg/l) & 151.1 & 39.4 & 15.0 & 534.0 & $186.3^{*}$ & 37.2 & 15.04 & 534.0 \\
\hline T.p.(gm/dl) & 5.5 & 0.38 & 5.02 & 7.35 & 6.02 & 0.69 & 5.07 & 7.87 \\
\hline Alb. (gm/dl) & 4.36 & 0.12 & 4.08 & 6.1 & 5.22 & 1.0 & 4.13 & 6.3 \\
\hline Calcium(mg/dl) & 11.78 & 0.24 & 7.89 & 11.2 & 11.78 & 0.82 & 8.3 & 12.93 \\
\hline Total Bilir. (mg/dl) & 0.41 & 0.27 & 0.0 & 1.195 & $0.25 *$ & 0.07 & 0.0 & 1.25 \\
\hline Direct Bilir. (mg/dl) & 0.19 & 0.03 & 0.0 & 0.3 & $0.13 *$ & 0.02 & 0.0 & 0.28 \\
\hline Uric acid(mg/dl) & 5.05 & 1.58 & 1.4 & 6.69 & 5.16 & 2.0 & 3.15 & 7.1 \\
\hline Creatinine(mg/dl) & 0.82 & 0.05 & 0.42 & 1.33 & 0.91 & 0.27 & 0.48 & 1.29 \\
\hline TIBC $(\mu \mathrm{g} / \mathrm{dl})$ & 186.8 & 32.1 & 85.54 & 510.2 & 228.9 & 29.9 & 88.8 & 482.2 \\
\hline $\operatorname{Iron}(\mathrm{mg} / \mathrm{l})$ & 1.6 & 0.19 & 0.03 & 1.69 & 1.7 & 0.12 & 0.3 & 1.64 \\
\hline Sulfate(mmol/l) & 2.5 & 1.05 & 2.21 & 6.78 & 3.3 & 1.09 & 2.0 & 7.8 \\
\hline GSH $(\mu \mathrm{mol} / \mathrm{l})$ & 13.7 & 0.89 & 4.73 & 22.7 & 12.7 & 2.0 & 3.73 & 20.7 \\
\hline $\operatorname{MDA}(\mu \mathrm{mol} / \mathrm{l})$ & 6.5 & 2.97 & 2.31 & 45.6 & $5.7 *$ & 2.4 & 2.44 & 44.34 \\
\hline Cholesterol(mg/dl) & 180.8 & 40.1 & 102.8 & 257.1 & 184.0 & 18.0 & 122.5 & 251.0 \\
\hline Glucose(mg/dl) & 68.1 & 35.8 & 57.2 & 123.5 & 61.69 & 5.6 & 67.2 & 128.7 \\
\hline Selenium $(\mu \mathrm{g} / \mathrm{dl})$ & 35.7 & 11.0 & 20.39 & 79.8 & 41.26 & 0.89 & 24.37 & 67.9 \\
\hline $\begin{array}{l}\text { Tansferrin } \\
\text { saturation \% }\end{array}$ & 36.65 & 13.5 & 25.14 & 39.21 & 34.26 & 4.8 & 23.41 & 38.24 \\
\hline
\end{tabular}

*Different Significantly at $\mathrm{P} \leq 0.05$.

The results showed that there was a significant decrease of suburbs smokers when compared with suburbs non-smokers in vitamin $\mathrm{C}(\mathrm{P}=0.03)$. Similar results were published by other investigators (Riemersma et al., 1991; Sakai et al., 1998; Pincemail et al., 2000; Lykkesfeldt et al., 2000; Nuttall et al., 2002). In vivo vitamin C has been suggested to be a biomarker of oxidant stress, and the level of vitamin $\mathrm{C}$ was 
decreased under the oxidant stress of smoking (Turnlund et al., 2004). Low vitamin C levels found in smokers are considered to be a direct consequence of vitamin $\mathrm{C}$ utilization as an antioxidant due to the smoke-related pro-oxidant load (Nuttall et al., 2002).

Other biochemical parameters were also decreased significantly as: total bilirubin $(\mathrm{P}=0.01)$, direct bilirubin $(\mathrm{P}=0.005)$ and malondialdehyde $(\mathrm{P}=0.019)$. These results were in a good agreement with the previously reported data (Al-Timimi and Al-Khayat, 2001).

Vitamin E, $\beta$-carotene and folic acid were not significantly decreased. These results meet with those of (Riemersma et al., 1991; Durand et al., 1997; Hippeli et al., 2003). The decreased in vitamin A, found in smokers is considered to be a direct consequence of its utilization as an antioxidant due to the smoke-related pro-oxidant load (EBSCO, 2005) similar to other reported results (Kim et al., 2004).

Glutathion wasn't decreased significantly and this finding was in a good agreement with others (Lykkesfeldt et al., 2000; Nuttall et al., 2002; Polidori et al., 2003; Detroit et al., 2003; Kim et al., 2004). Similarly glucose and transferrin saturation (\%) were decreased non significantly.

Moreover, it has been observed that there was a significant increase in: ceruloplasmin $(\mathrm{P}=0.004)$ which were similar to other reported results (Al-Timimi and AlKhayat, 2001; Sürmen-Gür et al., 2003).

The result of this study might suggest that the increase of $\mathrm{Cp}$. levels in smokers is a part of the total antioxidant status protecting tissues from the effects of free radicals (Al-Timimi and Al-Khayat, 2001;Sürmen-Gür et al., 2003), or might merely reflect increase copper intake from the tar component of the cigarettes (Duthie et al., 1991).

The results also showed non significant increase in: total protein, albumin, uric acid, creatinine, total iron binding capacity, iron, sulfate, cholesterol, selenium and calcium. This finding was in a good agreement with other (Wingerd and Sponzilli, 1977; Ryback et al., 1985; Chopra et al., 2000; Valkonen and Kuusi, 2000; Orth, 2002; Awadallah, 2003). Nephrologists "rediscovered" were reported that smoking as a major renal risk factor in 1997 (Orth et al., 1997).

\section{Effects of the smoking period on the biochemical parameters in smoking suburb group.}

Depending on the period of smoking, suburb smokers group was divided into three subgroups, which were listed in Table (3).

The results showed that vitamin $\mathrm{E}$ showed no changes with the increase of the period of smoking (Table 3). Notice that vitamin A significant decreased in (0-10 year) group and in (21year and over) group, but there were no significant differences between them.

$\beta$-carotene, vitamin $\mathrm{C}$ and folic acid were decreased significantly with the increase of the period of smoking. While no significant difference was observed in $\beta$-carotene. This result was in a good agreement with other reported results (Helen and Vijayammal, 1997).

Several studies have also examined the effect of vitamin $\mathrm{E}$ in cigarette smokers. Cigarette smoking stimulates the formation of highly reactive molecules. Serum levels of vitamin $\mathrm{E}$ (as well as vitamin $\mathrm{C}$ and $\beta$-carotene) react as antioxidant to these molecules. Therefore the level of vitamins were significantly lower in the smokers compared to the 
non-smokers, and antioxidant decreased too when the period of smoking increased (Hughes, 2000).

Table 3: The biochemical parameters of suburb smokers at different period of smoking and control using Duncan test.

\begin{tabular}{|c|c|c|c|c|c|c|c|c|}
\hline \multirow[t]{2}{*}{ Parameter } & \multicolumn{2}{|c|}{$\begin{array}{c}\text { Control group } \\
(n=59)\end{array}$} & \multicolumn{2}{|c|}{$(0-10$ year $) n=18$} & \multicolumn{2}{|c|}{$\begin{array}{c}(11-20 \\
\text { year }) n=16\end{array}$} & \multicolumn{2}{|c|}{$(21>$ year $) n=9$} \\
\hline & mean & SD & mean & SD & Mean & SD & mean & SD \\
\hline Age(year) & $35.7 \mathrm{c}$ & 10.9 & $27.98 \mathrm{~d}$ & 8.1 & $34.13 \mathrm{~b}$ & 6.67 & $42.0 \mathrm{a}$ & 6.17 \\
\hline Weight(kg) & $76.31 \mathbf{a}$ & 14.5 & $77.81 \mathbf{a}$ & 13.7 & $82.7 \mathbf{b}$ & 14.07 & $81.9 \mathbf{b}$ & 18.33 \\
\hline Height(cm.) & $169.0 \mathbf{a}$ & 10.57 & $170.48 \mathbf{a}$ & 8.3 & $173.1 \mathbf{a}$ & 8.07 & $169.0 \mathbf{a}$ & 9.5 \\
\hline B.M.I(k.g./m²) & $26.71 \mathrm{~b}$ & 2.45 & $26.92 \mathbf{b}$ & 2.45 & $27.6 \mathbf{a}$ & 2.08 & $28.67 \mathbf{a}$ & 1.98 \\
\hline Vit.E(mg/dl) & $1.0 \mathrm{a}$ & 0.21 & $0.99 \mathbf{a}$ & 0.14 & $0.96 \mathbf{a}$ & 0.12 & $0.92 \mathbf{a}$ & 0.15 \\
\hline Vit.A( $\mu \mathrm{g} / \mathrm{dl})$ & $46.42 \mathbf{a}$ & 12.4 & $42.76 \mathrm{c}$ & 18.84 & $48.2 \mathbf{b}$ & 10.3 & $42.05 \mathrm{c}$ & 15.3 \\
\hline$\beta$-carotene $(\mu \mathrm{g} / \mathrm{dl})$ & $80.49 \mathbf{a}$ & 21.52 & $63.0 \mathrm{a}$ & 9.6 & $70.6 \mathbf{a}$ & 8.7 & $73.59 \mathbf{a}$ & 11.9 \\
\hline Vit.C(mg/dl) & $0.85 \mathbf{b}$ & 0.17 & $0.88 \mathbf{a}$ & 0.17 & $0.42 \mathbf{c}$ & 0.08 & $0.33 \mathbf{d}$ & 0.024 \\
\hline Folic acid(ng/ml) & $6.85 \mathbf{a}$ & 1.7 & $6.96 \mathbf{a}$ & 1.18 & $6.61 \mathbf{a}$ & 1.6 & $5.34 \mathbf{b}$ & 1.71 \\
\hline Cp.(mg/l) & $151.1 \mathrm{~d}$ & 39.4 & $150.64 \mathrm{c}$ & 32.6 & $204.3 \mathbf{b}$ & 27.7 & $261.7 \mathbf{a}$ & 30.46 \\
\hline T.p.(gm/dl) & $5.5 \mathrm{a}$ & 0.38 & $6.02 \mathrm{a}$ & 0.69 & $5.24 \mathbf{a}$ & 0.74 & $5.14 \mathbf{b}$ & 0.89 \\
\hline Alb. (gm/dl) & $4.36 \mathbf{a}$ & 0.12 & $4.22 \mathbf{b}$ & 0.88 & $4.33 \mathbf{a}$ & 0.73 & $4.27 \mathbf{b}$ & 0.34 \\
\hline Calcium(mg/dl) & $11.78 \mathbf{a}$ & 0.24 & $11.85 \mathrm{~b}$ & 0.9 & $11.84 \mathrm{~b}$ & 0.66 & $11.44 \mathbf{b}$ & 0.92 \\
\hline Total Bilir. (mg/dl) & $0.41 \mathbf{a}$ & 0.27 & $0.16 \mathbf{b}$ & 0.08 & $0.12 \mathbf{b}$ & 0.01 & $0.11 \mathbf{b}$ & 0.07 \\
\hline $\begin{array}{l}\text { Direct Bilir. } \\
(\mathrm{mg} / \mathrm{dl})\end{array}$ & $0.19 \mathbf{a}$ & 0.03 & $0.14 \mathbf{b}$ & 0.06 & $0.11 \mathrm{a}$ & 0.08 & $0.13 \mathbf{b}$ & 0.07 \\
\hline Uric acid(mg/dl) & $5.05 \mathrm{~b}$ & 1.58 & $5.16 \mathrm{~b}$ & 1.10 & $5.64 \mathbf{a}$ & 1.23 & $5.98 \mathbf{a}$ & 0.52 \\
\hline Creatinine(mg/dl) & $0.82 \mathbf{a}$ & 0.05 & $0.94 \mathbf{a}$ & 0.1 & $0.84 \mathbf{a}$ & 0.12 & $0.87 \mathbf{a}$ & 0.13 \\
\hline TIBC $(\mu \mathrm{g} / \mathrm{dl})$ & $186.8 \mathbf{a}$ & 32.16 & $179.0 \mathbf{a}$ & 50.2 & $192.2 \mathbf{a}$ & 36.6 & $186.0 \mathbf{a}$ & 37.3 \\
\hline $\operatorname{Iron}(\mathrm{mg} / \mathrm{l})$ & $1.6 \mathrm{a}$ & 0.19 & $1.27 \mathrm{a}$ & 0.09 & $1.1 \mathrm{a}$ & 0.2 & $1.32 \mathbf{a}$ & 0.2 \\
\hline Sulfate(mmol/l) & $2.5 \mathbf{b}$ & 1.05 & $2.63 \mathrm{~b}$ & 1.14 & $2.66 \mathrm{~b}$ & 0.10 & $3.97 \mathbf{a}$ & 0.27 \\
\hline GSH $(\mu \mathrm{mol} / \mathrm{l})$ & $13.7 \mathbf{a}$ & 0.89 & $14.57 \mathbf{b}$ & 8.2 & $11.68 \mathrm{c}$ & 3.2 & $10.06 \mathrm{~d}$ & 1.3 \\
\hline $\operatorname{MDA}(\mu \mathrm{mol} / \mathrm{l})$ & $6.5 \mathbf{a}$ & 2.97 & $5.66 \mathbf{a}$ & 2.66 & $5.89 \mathbf{a}$ & 2.59 & $5.14 \mathbf{a}$ & 0.93 \\
\hline Cholesterol(mg/dl) & $180.8 \mathbf{d}$ & 40.13 & $184.0 \mathrm{~b}$ & 58.02 & $\begin{array}{c}194.51 \\
\text { c }\end{array}$ & 68.42 & $\begin{array}{c}223.54 \\
\mathbf{a}\end{array}$ & 66.21 \\
\hline Glucose(mg/dl) & $68.1 \mathrm{c}$ & 35.8 & $61.69 \mathrm{c}$ & 24.69 & $72.45 \mathrm{~b}$ & 42.13 & $85.64 \mathbf{a}$ & 29.58 \\
\hline $\operatorname{Selenium}(\mu \mathrm{g} / \mathrm{dl})$ & $35.7 \mathrm{c}$ & 8.06 & $37.1 \mathrm{c}$ & 9.69 & $54.4 \mathbf{a}$ & 9.01 & $40.41 \mathbf{b}$ & 8.42 \\
\hline $\begin{array}{l}\text { Tansferrin } \\
\text { saturation \% }\end{array}$ & $36.65 \mathbf{a}$ & 13.5 & $32.94 \mathbf{a}$ & 10.32 & $31.23 \mathbf{b}$ & 10.59 & $33.96 \mathbf{a}$ & 12.51 \\
\hline
\end{tabular}

Different letters horizontally a, b, c, d, indicate that the mean are different significantly at $\mathrm{P} \leq 0.05$.

Ceruloplasmin, on the other hand, increased with increasing the period of smoking and there was a significant difference within each one of the groups.

Total protein and albumin were significant difference in last groups (Table 3).

Calcium, total bilrubin and direct bilirubin were not affected with increasing the period of smoking and this result was agreement with literature (Chan-Yeung et al., 1981; Vogt, 1999). The mechanism of action of smoking on these parameters is unclear (Vogt, 1999). 
Uric acid, creatinine, TIBC and Iron increased significantly with the increase of the period of smoking, while TIBC and iron showed non a significant differences. Similar results were published by others (Chan-Yeung et al., 1981; Ahmad and Al-Helaly, 2002; Mannino et al., 2004).

Sulfate was increased with increasing period of smoking, where a significant difference among the groups was observed. The increase in sulfate might be due to the different compounds present in the smoking, especially $\mathrm{SO}_{2}, \mathrm{H}_{2} \mathrm{~S}$..etc.

Glutathion was decreased with the increase of the period of smoking and there was a significant difference among them. Nitric oxide in cigarettes might contribute to the GSH levels by directly reacting with glutathione and inhibiting antioxidants enzymes like glutathione reductase (Fechner et al., 2001).

Malondialdehyde wasn't affected, and this finding agrees with other observation that was found earlier (Helen and Vijayammal, 1997).

Cholesterol increased with increasing the period of smoking and showed significant difference in all groups as found in the literatures (Ahmad and Al-Helaly, 2002; Walker, 2003). The increase might be due to increase secretion of adrenaline hormone stimulated by the nicotine in cigarettes (Cryer et al., 1976). It is Known that adrenaline would increase the lipolysis and cholesterol level would be increased too (Burtis and Ashwood, 1999).

Glucose was increased with increasing the period of smoking and a significant difference among the groups was present. This finding agrees with the other observation found (Ko et al., 2001). It was reported that insulin concentration in smokers was decreased, and hence glucose would be increased (Burtis and Ashwood, 1999).

The results also showed that selenium was increased significantly with increasing the period of smoking and a significant difference among the groups was observed.

Transferrin Saturation (\%) on the other hand was decreased significantly and a significant difference among them was observed.

\section{RECOMMENDATIONS}

1.Smoking might be a contributing factor in increasing lead absorption among exposed people.

2.Avoidance of direct and indirect exposure to tobacco smoke is of primary importance not only for healthier lungs, but as a preventative measure for the other diseases: Cardiovascular disease, cancer, and diabetes, as well as the clinical importance of the present results suggesting that free radicals inhaled in cigarette smoke are highly toxic, and impaired oxidant-antioxidant balance is a risk factor in degenerative diseases. Therefore, may God help to prevent anything that affects the human body and lead to death:

\section{In the name of Allah Most Gracious Most Merciful.}

(The heifer) (195) And spend of your substance in the cause of Allah and make not your own hands contribute to your destruction but do good; for Allah loveth those who do good

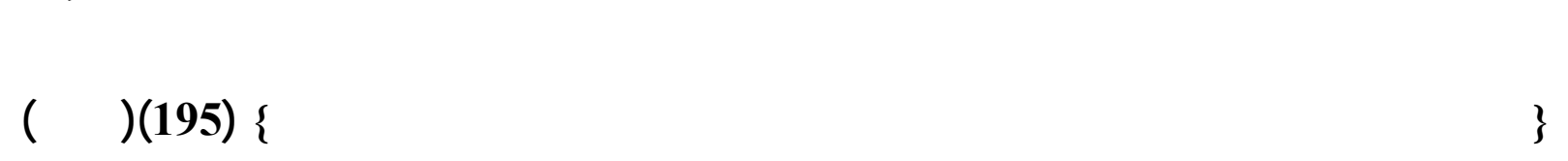




\section{REFERENCES}

Ahmad, T.Y., and Al-Helaly, L.A.A., 2002, Determination and Study the Normal Reference Values of Some Biochemical Parameters in Mosul City and its Suburbs. Raf. J. Sci. 13(2): pp.23-42. (Arabic).

Al-Abbad, F.A., and Al-Sowielem, L.S., 1998, Prevalence of Obesity.Saudi Med. J. 19(5): pp.608-613.

Al-Timimi, D.J., and Al-Khayat, A.M.S., 2001, Cigarette Smoking and Serum Ceruloplasmin. J. Fac. Med. Baghdad. 43(2): pp.297-300.

Association of Official Agricultural Chemists. 1950, Washington D.C. $7^{\text {th }}$ ed., 784p.

Awadallah, S.M., 2003, Haptoglobin 2-2 Phenotype is Associated With Decreased Ferroxidase Activity in Smokers. Clin. Chim. Acta. 334(1-2): pp.71-76.

Burtis, C.A., and Ashwood, E.R., 1999, Tietz Textbook of Clinical Chemistry. 3rd ed. W. B. Saunders Company, USA. pp.490, 482, 1048, 500, 1241.

Chan-Yeung, M., Ferreira, P., Frohlich, J., Schulzer, M., and Tan, F., 1981, The Effects of Age, Smoking, and Alcohol on Routine Laboratory Tests. A.J.C.P. 75(3): pp.320-326.

Chopra, M., O`Neill, M.E., Keogh, N., and Wortley, G., 2000, Influence of Increased Fruit and Vegetable Intake on Plasma and Lipoprotein Carotenoids and LDL Oxidation in Smokers and Nonsmokers. Clin. Chem. 46(11): pp.1818-1829.

Cryer, P.E., Haymond, M.W., Santiago, J.V., and Shah, S.D., 1976, Nor Epinephrine and Epinephrine Release and Adrenergic Mediation of Smoking- Associated Hemodynamic and Metabolic Events. New Engl. J. Med. 295(11): pp.573-577.

Detroit, M., Block, G., Norkus, E.P., Hudes, M., Traber, M.G., Cross, C.E., and Packer, L., 2003, Smoking and Exposure to Environmental Tobacco Smoke Decrease Some Plasma Antioxidants and Increase Gamma-tocopherol In vivo After Adjustment for Dietary Antioxidant Intakes. Am. J. Clin. Nutr. 77(1): pp.160166.

Doumas, B.T., Waston, W.A., and Bigg, H.G., 1971, Albumin Standards and the Measurement of Serum Abumin with BCG. Clin Chim Acta, 31: pp.87-96.

Durand, P., Prost, M., and Blache, D., 1997, Folic Acid Deficiency Enhances Oral Contraceptive-Induced Platelet Hyperactivity. Arterioscler. Thromb. Vasc. Biol. 17(10): pp.1939-46

Duthie, G.G., Arthur, J.R., and James, W.P., 1991, Effects of Smoking and vitamin E on Blood Antioxidant Satus. Am. J. Clin. Nutr. 53: pp.1061S-1063S.

EBSCO. 2005, Chronic Obstructive Pulmonary Disease. http://www.epnet.com.

Emmerie, A., and Engel, C., 1938, Nature, 142:873. Cited by Glick D. (1967). Methods of Biochemical Analysis. volume (2). John Wiley and Sons, Inc. 18p.

Fechner, A., Bohme, C.C., Gromer, S.M., and Funk, R., 2001, Antioxidant Status and Nitric Oxide in the Malnutrition Syndrome Kwashiorkor.Pediatr.Res.49: pp.237-243.

Gillham, B., Papachristodoulou, D.K., and Thomas, J.H., 2000, Wills 'Biochemical Basis of Medicine. 3rd ed. Butterworth-Heinmann. UK.

Helen, A., and Vijayammal, P.L., 1997, Vitamin C Supplementation on Hepatic Oxidative Stress Induced by Cigarette Smoke. J.Appl.Toxicol. 17(5): pp.289295. 
Hippeli, S., Dornisch, K., Brink, M., Lorenz, R., Jeschke, D., and Elstner, E.F.Z., 2003, Attenuation of Blood Parameters in Smokers and Non-smokers After Intake of a Complex Food Additive. Naturforsch-[C]. 58(1-2): pp.119-127.

Hughes, D.A., 2000, Dietary Antioxidants and Human Immune Function. Nutr. Bull., 25(1): $35 \mathrm{p}$.

Jaffe, M.Uber, denNiederschlag, Wwlchen Pikrinsaure in Normalem Harn Erzeugt and Uber Eine Neue Reaktion des Creatinine. Hoppe- Seylers, Z., 1886, Physiol. Chem. 10: pp.391-400. Cited by Haeckel, R., 1981. Clin. Chem. 27(1): pp.179183.

Kim., S.H., Ensunsa, J.L., Zhu, Q.Y, Kim, J.S., Shin, H.S., and Keen, C.L., 2004, An 18Month Follow-up Study on the Influence of Smoking on Blood Antioxidant Status of Teenage Girls in Comparison with Adult Male Smokers in Korea. Nutrition 20(5): pp.437-444.

Kingsley, G.R., 1942, The Direct Biuret Method for the Determinations of Serum Proteins as Applied to Photoelectric and Visual Colorimetry. J Clin. Lab. 27: pp.840-847.

Ko, G.T.C., Chan, J.C.N., Tsang, L.W.W., Critchley, J.A.J.H., and Cockram, C.S., 200, Smoking and Diabetes in Chinese men. Postgrad. Med. J.77: pp.240-243.

Liang, L., D'Haese, P., Lamberts, L.V., and DeBroe, M.E., 1989. Direct determination of iron in urine and serum using graphite furnace atomic absorption spectrometry. Analysis.114: pp.143-147.

Lunec, J., 1990, Review Articale, Ann. Clin. Biochem.27: 173p. Cited by Muslih, R.K., Al-Nimer, M.S., and Al-Zamely, O.M.Y., 2002. The Level of Malondialdehyde After Activition with $\left(\mathrm{H}_{2} \mathrm{O}_{2}\right.$ and $\left.\mathrm{CuSO}_{4}\right)$ and Inhibation by Desferoxamine and Molsidomine in the Serum of Patient with Acute Myocardial Infaraction.Nation. J.Chem. 5: pp.139-148.

Lykkesfeldt, J., Christen, S., Wallock, L.M., Chang, H.H., Jacob, R.A., and Ames, B.N., 2000, Ascorbate is Depleted by Smoking and Repleted by Moderate Supplementation: a Study in Male Smokers and Nonsmokers with Matched Dietary Antioxidant Intakes. Am. J. Clin .Nutr. 71(2): pp.530-536.

Mannino, D.M., Holguin, F., Greves, H.M., and Savage-Brown, A., 2004, Urinary Ccadmium Levels Predict Lower Lung Function in Current and Former Smokers. Thorax 59: pp.194-198.

Neeld, J.B., and Person, W.N., 1963, J.Nutr., 79:454p. Cited by Glick D., 1963. Methods of Biochemical Analysis. volume (15) .John Wiley and Sons, Inc. 18p.

Nuttall, S.L., Routledge, Manney, and H.C., S., 2002, Circulating and Exhaled markers of Nitric Oxide and Antioxidant Activity after Smoking.Circulation.106:e145p.

Orth, S.R., 2002, Smoking and the Kidney. J. Am. Soc. Nephrol. 13: pp.1663-1672.

Orth, S.R., Ritz, E., and Schrier, R.W., 1997, The Renal Risks of Smoking. Kidney Int. 51: pp.1669-1677.

Pincemail, J., Siquet, J., Chapelle, J.P., Cheramy-Bien, J.P., Paulissen, G., Chantillon, A.M., Christiaens, G., Gielen, J., Limet, R., and Defraigne, J.O., 2000, Determination of Plasma Concentrations of Antioxidants, Antibodies Oxidized LDL, and Homocysteine in a Population Sample from Liege. Ann. Biol. Clin. Paris. 58(2): pp.177-185. 
Polidori, M.C.; Mecocci, P.; Stahl, W., and Sies, H., 2003, Cigarette Smoking Cessation Increases Plasma Levels of Several Antioxidant Micronutrients and Improves Resistance Towards Oxidative Challenge. Br. J. Nutr. 90(1): pp.147-150.

Richmond, W., 1973, Preparation and Properties of a Cholesterol Oxidase from Nocardia Sp. And its Application to the Enzymatic Assay of Total Cholesterol. Clin. Chem. 19(12): pp.1350-1356.

Riemersma, R.A.; Wood, D.A.; Macintyre, C.C.A., and Elton, R.A., 1991. Risk of Angina Pectoris and Plasma Concentrations of Vitamins A, C, and E and carotene. Lancet 337(8732): pp.1-5.

Rbertson, W.G., and Marshall, R.W., 1979. Calcium Measurments in Serum and Plasma: Total and Ionized. Crit. Rev. Clin. Lab. Sci. 11: pp.271-304.

Roe, J.H., and Kuther, C.H., 1943. J.Biol.Chem.147: 399p. Cited by McMornick, D.B., and Wright, L.D., 1979. Mehods in enzymology. Volume (62). Vitamins and co enzymes. Part D. Academic press,Inc. 7p.

Ryback, R.S.; Rawlings, R.; Faden, V., and Negron, G.L., 1985, Laboratory Test Changes in Young Abstinent Male Alcoholics. A.J.C.P. 83(4): pp.474-479.

Sakai, N.; Yokoyama, T.; Date, C.; Yoshiike, N., and Matsumura, Y., 1998, An Inverse Relationship Between Serum Vitamin C and Blood Pressure in a Japanese Community. J. Nutr. Sci. Vitaminol. 44(6): pp.853-867.

Sedlak, J., and Lindsay, R.H., 1968, Anal. Biochem.192p. Cited by Al-Zamely, O.M.; Al-Nimer, M.S., and Al-Muslih, R.K., 2001. Detection the Level of Peroxynitrite and Related with Antioxidant Satus in the Serum of Pateints with Acute Myocardial Infarction.Nation. J.Chem.4: pp.625-637.

Snell, F.D., 1981, Photometric and Fluorometric Methods of Analysis non Metals. John Wiley and Sons, Newyork. pp.482-517.

Sunderman, F.W., and Nomato, S., 1970, Measurement of Human Serum Ceruloplasmin by its Para phenylenediamine Oxidase Activity. Clin. Chem. 16(11): pp.903910.

Sürmen-Gür, E.; Erdinc, A.; Serdar, Z., and Gür, H., 2003, Influence of Acute Exercise on Oxidative Stress in Chronic Smokers. J. Sp. Sci. Med. 2: pp.98-105.

Toro, G., and Ackermann, P.G., 1975, Practical Clinical Chemistry. Little, Brown and Company (Inc.).USA. pp.497-506.

Trinder, P.,1969, Determination of Glucose in Blood Using Glucose Oxidase with an Alternative Oxygen Acceptor. Ann. Clin. Biochem. 6: pp.24-27.

Turnlund, J.R.; Jacob, R.A.; Keen, C.L.; Strain, J.J.; Kelley, D.S.; Domek, J.M.; Keyes, W.R.; Ensunsa, J.L.; Lykkesfeldt, J., and Coulter, J., 2004, Long-term High Copper Intake: Effects on Indexes of Copper Status, Antioxidant Status, and Immune Function in Young Men. Am. J. Clin. Nutr. 79( 6): pp.1037-1044.

Valkonen, M.M., and Kuusi, T., 2000, Vitamin C Prevents the Acute Atherogenic Effects of Passive Smoking. Free Radic. Biol. Med. 28(3): pp.428-436.

Varley, H., 1967, Practical Clinical Biochemistry. $4^{\text {th }}$ ed.The White Friars Press Ltd. UK. $82 \mathrm{p}$.

Vogt, M.T., 1999, The Effect of Cigarette Smoking on the Development of Osteoporosis and related fractures. New Dimensions in Osteoporosis 1(5):pp.2-8.

Walker, H., 2003, Does Smoking Affect Blood Cholesterol Levels? http://www.ncbi.nlm.nih.gov/entrez/query.fcgi? 
Wingerd, J., and Sponzilli, E.E., 1977, Concentrations of Serum Protein Fractions in White Women: Effects of Age, Weight, Smoking, Tonsillectomy, and other Factors. Clin. Chem. 23(7): pp.1310-1317.

William, L.; White, J.M., and Flashka, C.M., 1977, The Measurment of Iron and Total Iron Binding Capacityby Using Calorimetric Test (Ferrozine).Clin. Chem.23: pp.237-239.

Zheng, X., 2003, Cigarette Smoke. Free Radical in Biology and Medicine 77:222, 7-April. 